\title{
Nutrient Requirements of Patients with Liver Cirrhosis
}

\author{
Tahira Sidiq* \\ Department of Home Science, University of Kashmir, India
}

Submission: March 08, 2017; Published: May 30, 2017

"Corresponding author: Tahira Sidiq, University of Kashmir, Hazratbal, Srinagar, Jammu and Kashmir 190006, India, Email: tahirasidiq86@gmail.com

\section{Mini Review}

In today's life people are not foremost concerned with one's health and well being as they are busy with other priorities. They develop bad eating habits, making poor lifestyle choices and neglecting different aspects of health. In turn, these habits affect their body and overall health of the people. The liver is one of the vital organs of our body, which is essential for one's health and wellbeing of an individual. One cannot survive in life without the liver as it performs everyday physiological functions in human life. So it is the job of an individual in maintaining his or her own health and wellbeing by protecting and nurturing the liver. If the patient has chronic liver disease he/she cannot realize it for many years as the liver has the capability function. Even the liver cirrhotic patients often have no symptoms in early stages and for this reason the liver is called as a "silent organ" of our body. The word "Cirrhosis" derives from the Greek word Kirrhos which means yellowish orange color of diseased liver of patient. WHO definition: a diffuse process characterized by liver necrosis and fibrosis and conversion of normal liver architecture into structurally abnormal nodules that lack normal lobular organization. The causes of Cirrhosis are myriad and it's considered as end stage disease of liver. Some times more than one factor is present in the same person. The principle causes of liver cirrhosis are; infection, poison, heart disease, chronic alcoholism, fatty liver, Protein calorie malnutrition, autoimmune disorders and inherited diseases such as haemochromatosis and Wilsons disease [1]. In liver cirrhotic patients malnutrition is a common complication which is associated with poor outcome. The various nutrient requirements of liver cirrhotic patients are as under

\section{Energy}

In liver cirrhosis the consumption of foods is difficult due to ascites and anorexia so the energy requirements vary among patients with cirrhosis. The patient needs highly nutritious food i.e. high calorie diet is necessary because of malnutrition [2]. In general, energy requirements for patients with end stage liver disease (ESLD) and without ascites are about $120 \%$ to $140 \%$ of the resting energy expenditure (REE). Requirements increase to $150 \%$ to $175 \%$ of REE if ascites, infection, or malabsorption is present or if nutritional repletion is necessary. This equates to about 25 to 35 calories/kg body weight; estimated dry body weight should be used in calculations to prevent overfeeding. Oral nutritional supplements or tube feeding can be effective in increasing or ensuring optimal intake in malnourished patients and reducing complications and prolonging survival [3]. Due to the increased prevalence of malnutrition, it is best to start nutrition at reduced calorie levels for the first 2-3 days to decrease the severity of "Refeeding Syndrome." Refeeding syndrome can occur in patients who have adapted to starvation, and then receive increased calories (especially carbohydrate). Initial calorie provision of $15-20 \mathrm{k}$ calories per kg of estimated body weight So calorie requirement of cirrhotic patients should be between 2000-3000Kcals.

Normal weight (height in centimeters minus 100) times $35=$ energy requirement in kilocalories per day.

Eg; A man of $174 \mathrm{~cm}$ requires about 2600 kilocalories while in hospital $(174-100=74,74$ times $35=2590 \mathrm{kcal})$. This diet should include from $90 \mathrm{~g}$ (compensated cirrhosis, good nutritional status) to $120 \mathrm{~g}$ (decompensated cirrhosis, malnutrition) of protein. $1 \mathrm{~g}$ of protein delivers 4 kilocalories (kcal) of energy [4].

\section{Protein}

In liver cirrhosis the high protein diet is helpful for regeneration of liver cells and to maintain the nitrogen balance but low enough to prevent hepatic coma. The protein content may vary in these patients as per symptoms. In Cirrhosis there is increased protein breakdown and inadequate resynthesis, resulting in depletion of visceral protein stores and muscle wasting. Nielson (1995) suggests that $0.8-1 \mathrm{~g}$ of protein $/ \mathrm{kg} /$ day is the mean protein requirement to achieve nitrogen balance. Therefore, in uncomplicated hepatitis or cirrhosis without encephalopathy, protein requirements range from 0.8 to $\mathrm{I} \mathrm{g} / \mathrm{kg}$ of dry weight per day to achieve nitrogen balance. To promote nitrogen accumulation or positive balance, at least 1.2 to $1.3 \mathrm{~g} / \mathrm{kg}$ daily is needed [5]. In case of alcoholic hepatitis or decompensate disease (sepsis, infection, gastrointestinal bleeding, severe 
ascites), at least $1.5 \mathrm{~g}$ of protein per kilogram per day should be provided [6]. If we want to provide additional protein, we have to give enteral or parenteral formulas that are low aromatic amino acids and high in branched chain amino acids. These patients may tolerate vegetable and dairy protein better than meat protein because they contain fewer ammonia containing substances and aromatic amino acids and more branched chain amino acids. In addition they provide more fibre which speeds up intestinal transit, thereby reducing the time available for production and absorption of ammonia in the body [7]. Vegetable protein contains more valine and is also higher in arginine, an amino acid that decreases blood ammonia levels through increasing urea synthesis. They are also lower in methionine and tryptophan, amino acids that exacerbate encephalopathy through gut conversion to neurotoxin metabolites [2].

\section{Carbohydrates ( $\mathrm{CHO})$}

Should be supplied liberally so that liver may store glycogen and liver function improves when the glycogen stores are adequate in liver cirrhotics. $60 \%$ of the calories should come from CHO so that liver damage is minimized [8]. Depending on the state of the liver, the carbohydrate should be adequate (300-400g/day) for its protein sparing effect. When $80 \%$ of hepatocytes are dysfunctional in cirrhotic patients, hypoglycemia is a frequent event due to hyper insulinemia. So correction of hypoglycemia with glucose administration can lead to resistant hyperglycemia. Therefore, multiple meals are required in order to provide a continuous and regulated flow of nutrients. Four to six meals rich in carbohydrates are recommended for liver cirrhotic patients $[9,2]$.

Fats

In liver cirrhosis, nausea is present in all patients so fat intake should be liberal as it makes food appetizing and provides efficient energy to the body. Plasma free fatty acids, glycerol and ketone bodies are increased in the fasting state. The fat is restricted only in the cirrhotic patients when they develop steatorrhoea. About 20g of fat is given. Medium chain triglycerides (MCT) may prove helpful in cirrhosis as they contain C8 and C10 fatty acids which are digested and absorbed in the absence of bile acids and they may prove to be effective in reducing malabsorption of fat. Coconut oil is recommended in liver cirrhotic patients as it contains MCT. 25 to $40 \%$ calories should be come from fats $[2,10,11]$.

\section{Vitamins and Minerals}

The liver is the major site of storage and conversion of vitamins into their metabolically active form. In liver cirrhosis there is deficiency of folate, vitamin A, riboflavin, nicotinamide, vitamin D, calcium, Zinc, Magnesium, pyridoxine and vitaminB12 vitamins. Fat soluble vitamins may be malabsorbed in liver cirrhosis. Supplementation with water soluble form of vitamins is desired to replenish liver stores and repair tissue damage especially if the patient has anorexia. Vitamin $\mathrm{K}$ is given intravenously or intramuscularly for 3 days to combat vitamin $\mathrm{K}$ deficiency which leads to prolonged prothrombin time. Large doses $(100 \mathrm{mg}$ ) of thiamin are given daily for a limited time if deficiency is present. Iron stores may be depleted in patients who were experiencing gastrointestinal bleeding. A vegetarian diet may be useful as additional therapy because copper is less available. Dietary copper restriction is not routinely prescribed unless other therapies are unsuccessful. Calcium, as well as magnesium and zinc may be mal absorbed with fatty liver. Therefore the patient should take supplements of these minerals also in their diet. Prescription of $1200-1500 \mathrm{mg}$ calcium and 400-800 IU vitamin D is advised. In the presence of osteoporosis the addition of biphosphonates is also recommended. Lack of vitamin A results in nyctalopia and dry cornea and so the use of 100,000-200,000 IU every 4 weeks is advisable. Parenteral administration of $10 \mathrm{mg}$ vitamin Kevery 4 weeks is recommended for liver cirrhotics. Anemia is common among cirrhotic patients so iron supplementation is essential. Ferrous sulphate $0.3 \mathrm{~g}$ tablet 3 times daily after meals should be given. Folic acid $1 \mathrm{mg} / \mathrm{d}$ orally is indicated in the treatment of macrocytic anemia $[2,10,12]$.

\section{Sodium}

In addition to diuretics in ascites, there should be restriction of fluid and sodium intakes also. Sodium is restricted only if edema and ascites are present. Evidence also indicates that sodium-restricted diet improve survival rate in these cases [13]. Generally $500 \mathrm{mg}$ sodium restricted diet or $2 \mathrm{~g} /$ day with diuretics are given. Take keen care in sodium content as less sodium increases the risk of hyponatremia. Emphasis should be given on low sodium diet and avoid table salt or prepared foods with too much salt. Serum sodium and potassium levels should be closely monitored $[10,13]$.

\section{Fluid}

Restriction of fluid intake $800-1000 \mathrm{ml} /$ day is required for patients with hyponatremia (serum sodium $<125 \mathrm{mEq} / \mathrm{l}$ ). If sodium is restricted efficiently fluid may not be severely restricted. Fluid requirement is generally worked out as per the previous day urinary output with addition to insensible losses. In order to assess the changes in fluid balance, weigh the person daily. Rapid weight gain indicates fluid retention and weight loss indicates excess fluid excretion. So keen observation should be taken to prevent worsening in these patients $[2,10,14,15]$.

\section{Fibre}

Reduction in fibre content is advised only in advanced cirrhosis in order to prevent danger of hemorrhage from esophageal varices. Hence, liquid, soft diet and small meals are emphasized in liver cirrhotics $[2,10,16]$.

\section{Branched-chain amino acids}

$65 \%$ to $90 \%$ of patients with cirrhosis have protein-energy malnutrition. Blood concentrations of branched-chain amino acid serve as both indicators of nutritional status and predictors 
of survival rate in liver cirrhosis [17]. 12 to 14 grams per day is effective in individuals with cirrhosis [18]. In a multicenter randomized trial of 646 patients with decompensated cirrhosis, the ingestion of $12 \mathrm{~g} /$ day of branched-chain amino acids over 2 years was associated with decreased mortality of around $35 \%$, compared with nutrition support from diet alone. Enteral feeding is also the recommended route for artificial nutrition in cirrhosis, and is associated with improved liver function and a lower hospital mortality rate [19].

\section{References}

1. Harrison SA, Torgerson S, Hayashi PH (2003) The natural history of nonalcoholic fatty liver disease: a clinical histopathological study. Am J Gastroenterol 98(9): 2042-2047

2. Shrilakshmi B Dietetics. ( $3^{\text {rd }}$ edn), New age international publication Ltd, pp. 233-240

3. Plauth M, Schütz T, Buckendahl DP, Kreymann G, Pirlich M, et al. (2004) Weight gain after transjugular intra hepatic protosystemics hunt is associated with improvement in body composition in malnourished patients with cirrhosis and hyper metabolism. J Hepato 40(2):228233.

4. Muller MJ, Boker KH, Selberg O (1994) Are patients with liver cirrhosis hyper metabolic. Clinical Nutrition 13(3): 131-144

5. Nielsen K, Kondrup J, Martinsen L, Døssing H, Larsson B, et al. (1995) Long-term oral refeeding of patients with cirrhosis of the liver. $\mathrm{Br} J$ Nutr 74(4): 557-567.

6. Matos C, Porayko MK, Francisco-Ziller N, DiCecco S (2002) Nutrition and chronic liver disease. J Clin Gastroenterol 35(5): 391-397.

7. Whitney E, Cataldo CB, Linda K, Debrauyne, Sharon R Rolfes. Nutrition for health and health care. West publishing company Minneapolis St. Paul New York Los Angeles, USA, pp. 573-576.

This work is licensed under Creative Commons Attribution 4.0 License

DOI: $10.19080 /$ CTBEB.2017.04.555645
8. Sobhonslidsuk A, Roongpisuthipong C, Nantiruj K, Kulapongse S, Songchitsomboon S, et al. (2001) Impact of liver cirrhosis on nutritional and immunological status. J Med Assoc Thai 84(7): 982-988.

9. Nakaya Y, Okita K, Suzuki K, Moriwaki H, Kato A (2007) BCAA-enriched snack improves nutritional state of cirrhosis. Nutrition 23: 113-120.

10. Indira Gandhi National Open University School of Continuing Education. Clinical Therapeutic Nutrition. Pp. 374-386.

11. Leery CM, Moroianu SA (2005) Nutritional aspects of alcoholic liver disease. Clin Liaer Dis 9(1): 67-81.

12. Brewer G (1993) Does a vegetarian diet control Wilson's disease? J Am Coll Nutr 12(5): 527-530.

13. Runyon BA (1998) Management of adult patients with ascites caused by cirrhosis. Hepatology 27: 264-272.

14. Gundling F, Teich N, Strebel HM, Schepp W, Pehl C (2007) Ernahrung beileberzirrhose. Med Klin 102: 435-444.

15. Gauthier A, Levy VG, Quinton A, H Michel, B Rueff (1986) Salt or no salt in the treatment of cirrhotic ascites: a randomized study. Gut 27(6): 705-709.

16. Williams (2005) Basic Nutrition and diet therapy. $12^{\text {th }}$ edition. Stael Nix Published by Elsevier, a division of led Elsevier India pvt Ltd,. pp. 341-342.

17. Moriwaki H, Miwa Y, Tajika M, Kato M, Fukushima H, et al. (2004) Branched-chain amino acids as a protein-and energy-source in liver cirrhosis. Biochem Biophys Res Commun 313(2): 405-409.

18. Laviano A, Muscaritoli M, Cascino A (2005) Branched-chain amino acids: the best compromise to achieve anabolism? Curr Opin Clin Nutr Metab Care 8(4): 408-414.

19. Muto Y, Sato S, Watanabe A, Moriwaki H, Suzuki K (2005) Effects of oral branched-chain amino acid granules on event-free survival in patients with liver cirrhosis. Clin Gastroenterol Hepatol 3(7): 705-713.

\section{Your next submission with Juniper Publishers will reach you the below assets}

- Quality Editorial service

- Swift Peer Review

- Reprints availability

- E-prints Service

- Manuscript Podcast for convenient understanding

- Global attainment for your research

- Manuscript accessibility in different formats

( Pdf, E-pub, Full Text, Audio)

- Unceasing customer service

Track the below URL for one-step submission https://juniperpublishers.com/online-submission.php 